D0I: https://doi.org/10.31874/2309-1606-2019-24-1-242-247

УДК: 37.03

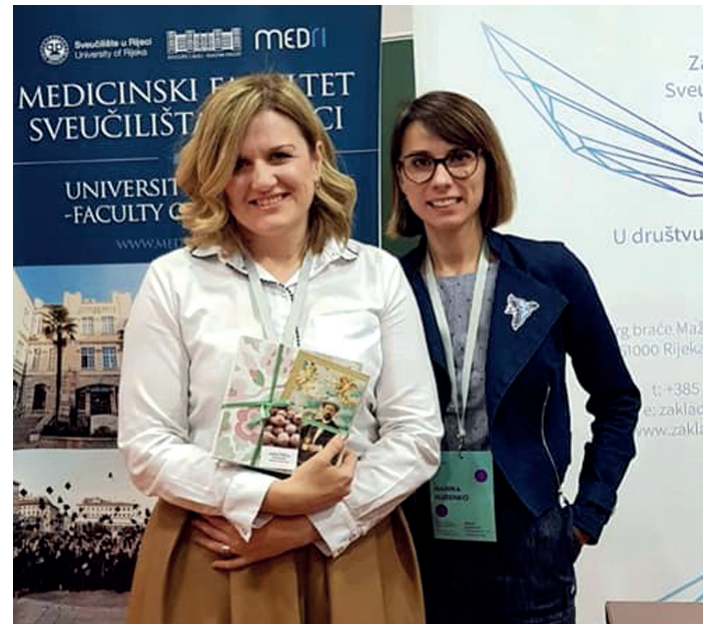

Hanna HUBENKO, Iva RINCIC

\title{
INTERVIEW WITH ASSOCIATE PROFESSOR OF RIJEKA UNIVERSITY IVA RINCIC
}

(The Interview has been conducted by Hanna Hubenko in terms of the International Conference «The $21^{\text {st }}$ Rijeka Days of Bioethics. Urban Bioethics: From Smart to Living Cities. Bioethical Debate, Reflections and Standards», Rijeka, Croatia, 17 - 18 May 2019)

\section{Annotation}

Interview with associate professor Iva Rincic feels like meeting a close-minded person on a very long journey. Meet and feel that you are "on the same page". What is urban bioethics? How is it different from bioethics in general? What is this "Project on Bioethical Urban Life Standards: The City as the Basis for Ethics Life"? - are the main points laid down in the conversation.

So, during the interview, you will find out that despite the fact that bioethics is perceived as a modern version of biomedical ethics, originally it covers a much wider area of interest. Bioethics implies moral obligations of people not only to each other, but also to everything living (animals and plants) (F. Jahr (1926)). This is the science of survival (V. R. Potter (1971)). If we see bioethics in this way, then urban life is necessary as a (bio) ethical object, purpose and scope, and "the city as a living creature that is constantly growing and transforming." Within the framework of the project the main goal is to create a list of urban bioethics standards. In order to activate the mechanism of urban bioethics, Iva talks about such valuable characteristics of local people as Responsibility, Committment, Awareness, Trust, Belonging. 
The project "European Bioethics in Action" fed into the list of bioethical standards. Iva Rincic also presented a list of 97 standards that determine relationships between animals, plants, people and environment. Further this list will be simplified for residents of the city. Iva wants all citizens to be included in these lists. She is also sure that this is the only way to have a rather bright tool to achieve bioethical city in the future.

Key words: European bioethics, bioethical standards of urban life, urban bioethics.

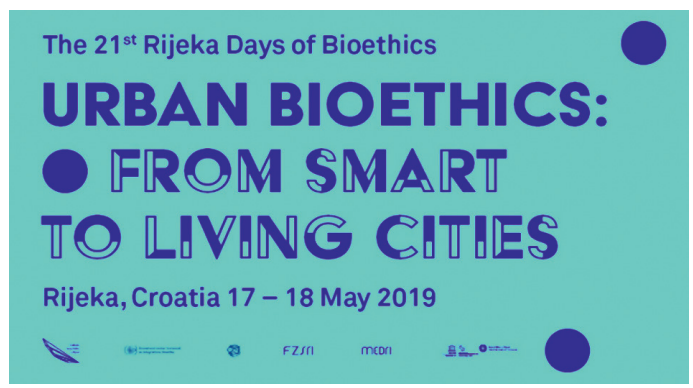

\section{H.H.: What is Urban Bioethics (UB) and how is it different from bio- ethics in general?}

I.R.: In answering this question, I would start with very short explanation of bioethics in general. Although today often understood as a modern version of biomedical ethics, bioethics in its origin encompasses much broader field of interest. According to F. Jahr (1926) bioethics (or Bio-Ethik) is logical step forward after bio-psychology, introducing thesis about moral duties of people not only toward each other, but also all human beings (animals and plants). He summarizes his position in formulation of Bioethical imperative: „Respect every living being as an end in itself, and threat it, if possible, as such!“. In 1971 V. R. Potter proposed bioethics as a new science, kind of a bridge to future, solution for connecting natural sciences with much needed lost human values, as a way of providing solution for our survival.

If we see bioethics in this manner, and of course are aware of the challanges of modernity, urbanity is much needed as (bio)ethical object, aim and field, as „city as being is in a permanent process of creation and transformation“ (Araujo, 2015). Urban bioethics, as we see it, is branch of general bioethics devoted to (bio)ethical research and applications related to city, including health and medicne, but also going broader in terms of themes and topics (energy, natural resources, traffic, architecture, safety...).

H.H.: What are the UB implementation mechanisms you offer to use?

I.R.: Our starting point is list of bioethical standards, results of our previous project (European Bioethics in Action 2014-2017), funded by Croatian Science Foundation: 
http://eurobioact.uniri.hr/files/Djelatnosti/Rezultati-projekta/The\%20 List $\% 20$ of\%20Bioethical\%20Standards.pdf

The primary goal of bioethical standards was to provide decision makers at the level of local self-government with a list of concrete guidelines that should lead to an improvement in the relationship between people and the environment (primarily but not exclusively the living environment) with the ultimate aim of preserving health and improving the quality of life of people, and protecting biodiversity and other natural resources with respect to local economic plans and choices ('sustainable development').

What is our aim within urban bioethics project is creatin a list of urban related bioethical standards.

\section{H.H.: Do you adhere to the principles of urban bioethics in your country?}

I.R.: Rijeka and Croatia have long tradition of bioethics, including very active domain of meetings, publications and public consultation. What we can also see is existence and dialogue of different perspectives and disciplines, but also innovative concepts and proposals (integrative bioethics).

However, it would be brave to claim we have reached admissible level of bioethical sensitivity, including adhering of the principles of urban bioethics. Number of daily problems and lack of social responsibility on various level do jeopardize achievement of significant stepy forward. Our aim is to think globally (urbanisation), but to (first) act locally, trying to prepare list of urban bioethical standards relevant for Rijeka context. Being European Capital of Culture 2002 give us even stronger impetus.

H.H.: Explain what the new mentality of both professionals and all citizens is based on - what are the implications, characteristics, etc., in order to begin the action of UB?

I.R.: Responsibility, Committment, Awareness, Trust, Belonging.

H.H.: Tell about the European Bioethics program in Action project, is this an opportunity to get acquainted with bioethical standards for example, on the site?

I.R.: Project European Bioethics in Action was divided in 4 stages (1. Deepening the theoretical basis. 2. Analysis of the situation in local communities, 3. Workshops, 4. Creation of a bioethical standards list). The proposed methodology was:

- Multi-Perspective Methodology - encompassing different perspectives of the same problem or process, and result in orientation platform knowledge that helps prevent and solve complex environmental issues;

- Open Method of Coordination - moving norms to a higher level and their application at the local level in an appropriate way; 
- Precautionary Principle - taking certain measures to prevent possible adverse consequences.

Current list of 97 standards define relation toward animals, plants, people and environment. By the end of this project we have discussed this the bioethical list proposal with representatives of local communities, getting very useful insights and comments. What we passed is to see whether there are standards going even beyond categories of people, animals, plants and enviroment and are related to city. If we manage to create this list, it should be easier for people,+ living in this cities, but also local politicians to adhere to them. This is also one of the reasons why we want citizens perspectives to be included already in list creation.

\section{H.H.: Which bioethical standards can be basis of urban bioethics?}

I.R.: This is probably the hardest intelectual challange of the project, that is why we wanted to gather scholars from different cultures and disciplines to discuss urban bioethics. In order to achieve this, we plan to use the European Bioethics in Action methodology, so now we are somewhere between deepening the theoretical basis and analysis of the situation in local communities. Last thing we want to end with is monodisciplinary bioethical list.

However, so far we already have identifies categories that will cover different sectors, this is just a starting point but do reflects pluriperspectives we want to achive (Non-human urban settlers (animals, pets, plants, biodiversity...), Pollution and climate change (air, sound and light pollution; waste managment...), Urban health (obesity, mental health, depression, epidemiology...), Food (urban gardening, food deserts...), Landscape (water, city forests, parks...), Built environment (architecture, heritage...), Culture and social services (play, housing, social support, local economy, education...), Technology and design (communication, design), Traffic and safety (public transport, parking, security), Energy ... The list is already long and demanding, but it is always open for new proposals and directions, thsi is only way to have really vivid tool for achieving bioethical city in the future.

Інтерв’ю з доценткою Рієцького Університету Івою Рінчіч (інтерв'ю провела Ганна Губенко в рамках міжнародної конференції «The $21^{\text {st }}$ Rijeka Days of Bioethics. Urban Bioethics: From Smart to Living Cities. Bioethical Debate, Reflections and Standards», Рієка/Хорватія, 17-18 травня 2019 року)

Інтерв'ю з доценткою Івою Рінчіч - це як зустріти однодумницю на дуже довгому шляху. Зустріти і відчути, що ви «на одній хвилі» і так приємно купатися в цих хвилях. Що таке урбаністична біоетика? Як пов'язане нове поняття з біоетикою в цілому? Що це за проект «Біоетічні стандарти міського життя: Місто як основа для Етики Життя»? - основні пункти, що закладені в бесіді. 
Отже, в процесі інтерв'ю ви дізнаєтеся, що незважаючи на те, що біоетика сприймається як сучасна версія біомедичної етики, - вона охоплює набагато ширшу сферу інтересів. Біоетика - це моральні зобов'язання людей не тільки один перед одним, а й перед усім живим (тваринами і рослинами) (Ф. Яр (1926)). Це наука виживання (В. Р. Поттер (1971)). Якщо ми бачимо біоетику таким чином, то міське життя необхідний - (біо) етичний об'єкт, мета і сфера, а «місто це жива істота, що постійно зростає і трансформується». В рамках проекту головною метою є створення списку міських стандартів біоетики. А щоб привести в дію механізм урбаністичної біоетики, Іва говорить про такі ціннісні характеристики місцевих жителів як відповідальність, відданість, обізнаність, довіру, приналежність.

Проект «Європейська біоетика в дії» ліг в основу списку біоетичних стандартів. Іва Рінчіч також представила список з 97 стандартів, які визначають ставлення до тварин, рослин, людей та навколишнього середовища. Далі цей список буде спрощено для жителів міста. Іва сподівається, що думки всіх громадян будуть враховані в цих списках. Вона також впевнена, що це єдиний спосіб, щоб мати дійсно яскравий інструмент для досягнення біоетичного міста в майбутньому.

Ключові слова: європейська біоетика, біоетичні стандарти міського життя, урбаністична біоетика

Iva Rincic, $\mathrm{BA}, \mathrm{MA}, \mathrm{PhD}$

Associate Professor Department of Social Sciences and Medical Humanities/ Department of Public Health; Faculty of Medicine/Faculty of Health Studies University of Rijeka

Іва Рінчич, BA, MA, PhD

Доцентка кафедри соціально-гуманітарних та медичних наук / кафедра громадського здоров'я; Медичний факультет / Факультет медико-санітарних досліджень Університету Рієка

Ганна Губенко, к.філос.н., доцент кафедри громадського здоров'я медичного інституту СумДУ; голова ГО «Біоетика». E-mail: hanna.hubenko@ gmail.com; bioethics.ngo@gmail.com

Hanna Hubenko, Ph.D.,Associate Professor of the Department of Public Health of the Medical Institute (Sumy State University (SSU)); The Founder\&Head of «Bioethics» NGO. E-mail: hanna.hubenko@gmail.com

bioethics.ngo@gmail.com

Интервью с доценткой Университета Риеки Ивой Ринчич (интервью провела Анна Губенко в рамках международной конференции «The 21st Rijeka Days of Bioethics. Urban Bioethics: From Smart to Living Cities. Bioethical Debate, Reflections and Standards», Риека/Хорватия, 17-18 мая 2019 год) 
Интервью с доценткой Ивой Ринчич это как встретить единомышленницу на очень долгом пути. Встретить и почувствовать, что вы «на одной волне» и так приятно купаться в этих волнах. Что такое урбанистическая биоэтика? Как она связана с биоэтикой в целом? Что это за «Проект по Биоэтичным Стандартам Городской Жизни: Город как основа для Этики Жизни»? - основные пункты, заложенные в беседе.

Итак, в процессе интервью вы узнаете, что несмотря на то, что биоэтика воспринимается как современная версия биомедицинской этики, изначально она охватывает гораздо более широкую сферу интересов. Биоэтика это моральные обязательства людей не только друг перед другом, но и перед всем живым (животными и растениями) (Ф. Яр (1926)). Это наука выживания (В. Р. Поттер (1971)). Если мы видим биоэтику таким образом, то городская жизнь необходима как (био)этический объект, цель и сфера, а «город как живое существо, которое постоянно растет и трансформируется». В рамках проекта главной целью является создание списка городских стандартов биоэтики. А чтобы привести в действие механизм урбанистической биоэтики, Ива говорит о таких ценностных характеристиках местных жителей как ответственность, приверженность, осведомленность, доверие, принадлежность.

Проект «Европейская биоэтика в действии» лег в основу списка биоэтических стандартов. Ива Ринчич также представила список из 97 стандартов, которые определяют отношение к животным, растениям, людям и окружающей среде. Далее этот список будет упрощен для жителей города. Ива хочет, чтобы мнения всех граждан были учтены в этих списках. Она также уверенна, что это единственный способ, чтобы иметь действительно яркий инструмент для достижения биоэтического города в будущем.

Ключевые слова: европейская биоэтика, биоэтические стандарты городской жизни, урбанистическая биоэтика.

Project Bioethical Standards of Urbanity: City as a Framework for Life Ethics (with special regard to Rijeka) (SUBethos) Funded by University of Rijeka (unirihuman-18-49), 2019-2021

Iva Rincic, BA, MA, PhD. Associate Professor Department of Social Sciences and Medical Humanities/Department of Public Health; Faculty of Medicine/ Faculty of Health Studies University of Rijeka

Hubenko Hanna, Ph.D. Associate Professor of the Department of Public Health of the Medical Institute (Sumy State University (SSU));

The Founder\&Head of «Bioethics» NGO

E-mail: hanna.hubenko@gmail.com

bioethics.ngo@gmail.com 